\title{
T7 - El injerto en tomate (Solanum licopersicum Mill.) alternativa al cambio climático
}

\author{
Santiago Maradiaga \\ Universidad Nacional de Agricultura, Catacamas, Honduras.
}

*Autor al que se dirige la correspondencia: smaradiagarodrigue@yahoo.com

\section{Resumen}

E n la actualidad la producción de hortalizas a campo abierto en Honduras se ha vuelto difícil para poder concluir el ciclo vegetativo por las inclemencias del cambio climático que en la mayoría de las áreas con potencial para establecer esto cultivos sobre todo las solanáceas y cucurbitáceas son afectados por enfermedades de origen telúrico. Estos organismos causan considerables pérdidas en los rendimientos. El injerto herbáceo es una práctica cultural que confiere a las plantas una mayor tolerancia frente a los factores abióticos (temperatura, salinidad, estrés hídrico, etc.). En la Universidad Nacional de Agricultura se ha venido investigando con esta técnica a cielo abierto con resultados aceptables sin desmejorar los rendimientos y calidad. Se evaluó el comportamiento de dos portainjertos criollos en tomate con dos variedades de uso común en los productores Pony y Belfas donde los tratamientos fueron T1 (Cherry/Pony), T2 (Cherry/Belfast), T3 (Belfast/Pony), T4 (Pony) y T5 (Belfast). Se utilizó un diseño en bloques completos al azar con tres repeticiones, las variables evaluadas fueron: Porcentaje de pegue, compatibilidad, altura de planta, días a floración, diámetro de tallo, calibres de fruto, grados brix en el fruto, biomasa fresca de la raíz, numero de frutos por planta y rendimiento. Los resultados obtenidos para todas las variables muestra que las plantas injertadas mostraron mayores valores que las no injertadas, resaltando rendimiento donde el T1 reporto 60 ton/ha en relación al testigo 40 ton/ha.

Palabras claves: Injerto herbáceo, variedades de tomate.

\begin{abstract}
$\mathrm{N}$ owadays the production of vegetables at open field in Honduras has become difficult to conclude the vegetative cycle by climatic change that in the majority of areas with potential for establishing this crop mostly the Solanaceae and Cucurbitaceae are affected by diseases of telluric origin. These organisms cause considerable losses in those yields. Herbaceous grafting is a cultural practice that gives plants a higher tolerance against abiotic factors (temperature, salinity, water stress, etc.). Herbaceous grafting is a cultural practice that gives plants a higher tolerance against abiotic factors (temperature, salinity, water stress, etc.). At the National University of Agriculture is has been investigated with this technique at open field with acceptable results without losing yields and quality. We evaluated the behavior of two criollos rootstocks of tomato with two varieties of common use, Pony and Belfast; the treatments were T1 (Cherry/Pony), T2 (Cherry/Belfast), T3 (Belfast/Pony), T4 (Pony) and T5 (Belfast). We used a complete blocks design with three random replicates, the evaluated variables were: Percentage of graft paste, compatibility, plant height, days to flowering, stem, fruit, degrees brix in result sizes, diameter fresh root biomass, number of fruits per plant and performance. The results obtained for all variables shows that the grafted plants showed higher values than the not grafted, highlighting performance where T1 reported 60 ton/ has in relation to witness 40 ton/has.
\end{abstract}

Keywords: Herbaceous grafting, tomato varietiesk. 